Jurnal Mekanova

Vol 5. No. 2, Oktober 2019

ISSN : 2502-0498

\title{
Kemampukerasan Baja Tahan Karat AISI 304
}

\author{
*11Herdi Susanto, ${ }^{2}$ Pribadyo, dan ${ }^{3}$ Rahmad Novizar \\ 1,2,3 Jurusan Teknik Mesin, Fakultas Teknik, Universitas Teuku Umar \\ Meulaboh 23681 Aceh Barat, Indonesia \\ "Email: herdisusanto@utu.ac.id
}

\begin{abstract}
Abstrak
Baja tahan karat AISI 304 secara umum digunakan pada mesin-mesin konstruksi terapan sederhana seperti poros propeler kapal nelayan, mesin penghancur es, pemeras tebu dan lainnya, dikarenakan ketahanan korosifnya yang baik, disisi lain kelemahan AISI 304 pada kondisi lapangan sering mengalami deformasi dan kepatahan dengan putaran yang relatif tinggi. Untuk mengatasi hal tersebut dapat dilakukan usaha menambah nilai kekerasan permukaan dengan melakukan pengujian Jominy Hardenability. Pengujian Jominy yang dilakukan pada spesimen uji dengan standar ASTM A255-02, dengan laju air pada nozzle 45 liter/menit, pada temperature $850^{\circ} \mathrm{C}$ dan holding time 15-20 menit. Hasil pengujian menunjukkan bahwa nilai awal kekerasan permukaan pada ujung quenching sisi A adalah $187 \mathrm{HB}$ dan pada sisi B adalah $170 \mathrm{HB}$. Nilai kekerasan permukaan setelah di normalizing pada ujung quenching sisi $A$ adalah $182 \mathrm{HB}$ dan pada sisi B adalah 188 HB. Maka terjadi penurunan kekerasan pada sisi A sebesar 5 HB, dan terjadi peningkatan kekerasan pada sisi B sebesar 18 HB. Setelah di uji Jominy nilai kekerasan pada sisi A adalah 227 HB, dan pada sisi B adalah 223 HB. Pada pengujian jominy terjadi peningkatan kekerasan pada ujung sisi A sebesar $45 \mathrm{HB}$, dan peningkatan kekerasan pada sisi B sebesar $35 \mathrm{HB}$. Hasil penelitian ini dapat direkomendasikan bahwa AISI 304 sebelum digunakan sebaiknya dilakukan pengerasan permukaan sehingga sifat mekanik bahan menjadi lebih optimal.
\end{abstract}

Keywords : Uji Jominy, AISI 304 , Normalizing, ASTM A255-02

\begin{abstract}
Stainless steel AISI 304 is commonly used in simple applied construction machines such as propeller ships, fishing boats, ice crushers, sugarcane squeeze and others, due to its good corrosive resistance, on the other hand the weakness of AISI 304 on field conditions is often deformed and fracture with relatively high spin. To overcome this can be done effort to increase the value of surface hardness by doing Jominy Hardenability testing. Jominy test was performed on test specimen with ASTM A255-02 standard, with water rate at 45 liters / minute nozzle, at 8500C and holding time 15-20 min. The test results show that the initial surface hardness value at the end of quenching side $A$ is 187 $H B$ and on side $B$ is $170 \mathrm{HB}$. The surface hardness value after normalizing on the edge of the A side quenching is $182 \mathrm{HB}$ and on the $B$ side is $188 \mathrm{HB}$. Then there is a decrease in hardness on the $A$ side of $5 \mathrm{HB}$, and an increase in hardness on the B side of $18 \mathrm{HB}$. After the Jominy test the hardness value on the A side is $227 \mathrm{HB}$, and on the B side is 223 $H B$. In jominy testing there was an increase in hardness at the tip of side $A$ of $45 \mathrm{HB}$, and an increase in hardness on the $B$ side of $35 \mathrm{HB}$. The results of this study can be recommended that AISI 304 before use should be done surface hardening so that the mechanical properties of the material becomes more optimal.
\end{abstract}

Keywords : Jominy hardenability test, AISI 304, Normalizing, ASTM A255-02 


\section{PENDAHULUAN}

Hardenability adalah ukuran kemampuan suatu material untuk membentuk fasa martensite. Hardenability dapat diukur dengan beberapa metode. Diantaranya metode Jomini dan metode Grossman. Dari metode tersebut kita akan mendapatkan kurva antara harga kekerasan dengan jarak quenching dari pusat quench [1].

Baja tahan karat AISI 304 banyak digunakan untuk kontruksi-kontruksi mesin terapan seperti poros propeler perahu nelayan, alat penghancur es batu, pemeras tebu, dan lain sebagainya. Karena sifat ketahanan korosinya yang baik, kondisinya dilapangan sering mengalami kebengkokan (deformasi) dan kepatahan dengan beban yang relatif tinggi. Untuk mengatasi hal tersebut dapat dilakukan dengan teknik Hardenability.

Baja tahan karat AISI 304 dapat ditingkatkan kekerasan nya melalui pengerjaan dingin, kemampu kerasan baja tahan karat AISI 304 menunjukan peningkatan kekuatan melalui transformasi martensit pada permukaan material sehingga di harapkan kekuatan bahan pada permukaan meningkat.[2]

Untuk meningkatkan kemampu kerasan baja tahan karat AISI 304 di penelitian ini menggunakan metode Jomini. Sebelum dilakukan uji Hardenability Jomini baja tahan karat AISI 304 dibuat berbentuk batang silindris dengan diameter 1 inchi dan panjang 4 inchi, salah satu ujungnya diperlebar untuk memudahkan batang uji tersebut digantungkan pada peralatan quench [5].

Berdasarkan latar belakang diatas pada penelitian ini dilakukan Uji Hardenability Baja Tahan Karat AISI 304 untuk meningkatkan sifat mekanik.

\section{METODE PENELITIAN}

\subsection{Tempat dan Waktu Penelitian}

Penelitian ini dilakukan selama 6 (enam) bulan untuk mencapai target yang di tentukan. Pekerjaan persiapan dan pengujian serta segala sesuatu yang akan dilakukan di Laboratorium atau Workshop Teknik Mesin UTU. Setiap kejadian, respon dan hasil yang diperoleh selama menjalankan kegiatan dicatat dalam dokumentasi dengan bantuan komputer untuk menjamin akuntabilitas hasil penelitian. Rangkaian kegiatan yang dilakukan dalam penelitian ini dapat dilihat dalam Gambar 1.

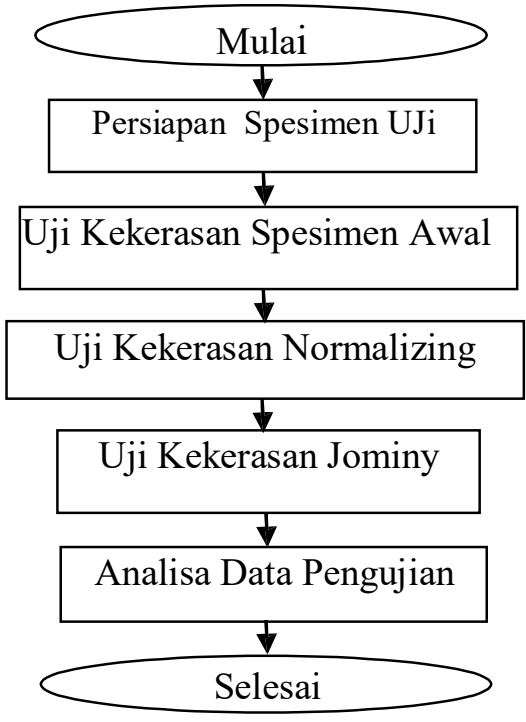


Jurnal Mekanova

Vol 5. No. 2, Oktober 2019

ISSN : 2502-0498

Gambar 1. Diagram alir penelitian 
Vol 5. No. 2, Oktober 2019

ISSN : 2502-0498

\subsection{Spesimen bahan uji}

Baja stainless steel sedang digunakan sebagai bahan penelitian Jominy Hardenability Test. Baja tahan karat AISI 304 adalah salah satu jenis baja stainless austenitic.

Baja austenitic ini mempunyai struktur kubus satuan bidang (face center cubic) dan merupakan baja dengan ketahanan korosi tinggi. Komposisi unsur - unsur pemadu yang terkandung dalam AISI 304 akan menentukan sifat mekanik dan ketahanan korosi. Baja AISI 304 mempunyai kadar karbon sangat rendah 0,08\%wt. Kadar kromium berkisar $18-20 \%$ wt dan nikel $8-10,5 \%$ wt yang terlihat pada Tabel 1. Kadar kromium cukup tinggi membentuk lapisan $\mathrm{Cr}_{2} \mathrm{O}_{3}$ yang protektif untuk meningkatkan ketahanan korosi. Komposisi karbon rendah untuk meminimalisai sensitasi akibat proses pengelasan.

Tabel 1. Komposisi kimia baja tahan karat AISI 304

\begin{tabular}{|c|c|}
\hline Unsur & \%wt \\
\hline $\mathrm{C}$ & 0,08 \\
\hline $\mathrm{Mn}$ & 2 \\
\hline $\mathrm{P}$ & 0,45 \\
\hline $\mathrm{S}$ & 0,03 \\
\hline $\mathrm{Si}$ & 0,75 \\
\hline $\mathrm{Cr}$ & $18-20$ \\
\hline $\mathrm{Ni}$ & $8-10,5$ \\
\hline $\mathrm{Mo}$ & 0 \\
\hline $\mathrm{Ni}$ & 0,10 \\
\hline $\mathrm{Cu}$ & 0 \\
\hline $\mathrm{Fe}$ & Balance \\
\hline
\end{tabular}

Sumber: Metals Handbook, Vol. 1, America Society for Metals, Ohio, 1961.

Tabel 2 Sifat mekanik dari baja tahan karat AISI 304 :

\begin{tabular}{|c|c|c|c|c|c|}
\hline \multirow[b]{2}{*}{ Grade } & \multirow{2}{*}{$\begin{array}{c}\text { Kekuatan } \\
\text { tarik } \\
(\mathrm{MPa}) \\
\text { min }\end{array}$} & \multirow{2}{*}{$\begin{array}{c}\text { Yield } \\
\text { Kekuatan } \\
0,2 \% \text { Proof } \\
(\mathrm{MPa}) \mathrm{min}\end{array}$} & \multirow{2}{*}{$\begin{array}{c}\text { Pemanjangan (\% } \\
\text { dalam } 50 \mathrm{~mm}) \\
\min \end{array}$} & \multicolumn{2}{|c|}{ Kekerasan } \\
\hline & & & & $\begin{array}{l}\text { Rockwell B } \\
\text { (HR B) max }\end{array}$ & $\begin{array}{c}\text { Brinell } \\
\text { (HB) } \\
\max \end{array}$ \\
\hline 304 & 515 & 205 & 40 & 92 & 195 \\
\hline
\end{tabular}

Sumber: Metals Handbook, Vol. 1, America Society for Metals, Ohio, 1961.

\subsection{Ukuran spesimen uji}

Dimensi dan ukuran spesimen dibuat berdasarkan standar ASTM A 255-02, seperti terlihat pada gambar 2 . 


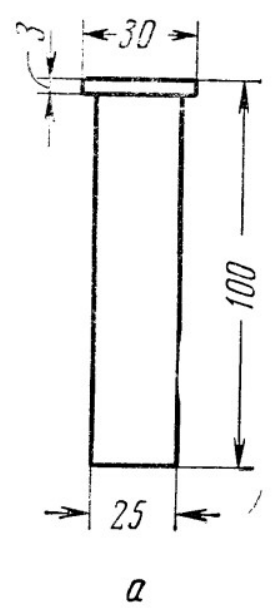

Gambar 2. Dimensi dan ukuran spesimen Uji Hardenability Jominy

\subsection{Peralatan Kerja}

Sumber : ASTM A 255-02.

Peralatan kerja yang digunakan dalam pengujian spesimen baja tahan karat AISI 304 adalah sebagai berikut :

2.4.1. Hardenability Jominy beserta kelengkapannya.

Alat Uji Jominy digunakan untuk melaksanakan pengujian, suatu batang uji dengan panjang $100 \mathrm{~mm}$ dan diameter $25 \mathrm{~mm}$, salah satu ujungnya diperlebar untuk memudahkan batang uji tersebut digantungkan pada peralatan quench. Batang uji tersebut dipanaskan pada tempratur austenisasi dan holding time 15-20 menit. Setelah proses pemanasan selesai, batang uji digantungkan pada peralatan quench dan kemudian salah satu ujungnya dicelupkan dengan cepat pada air yang kecepatan debit air 45 liter/menit [6]. Ditunjukkan pada Gambar 3.

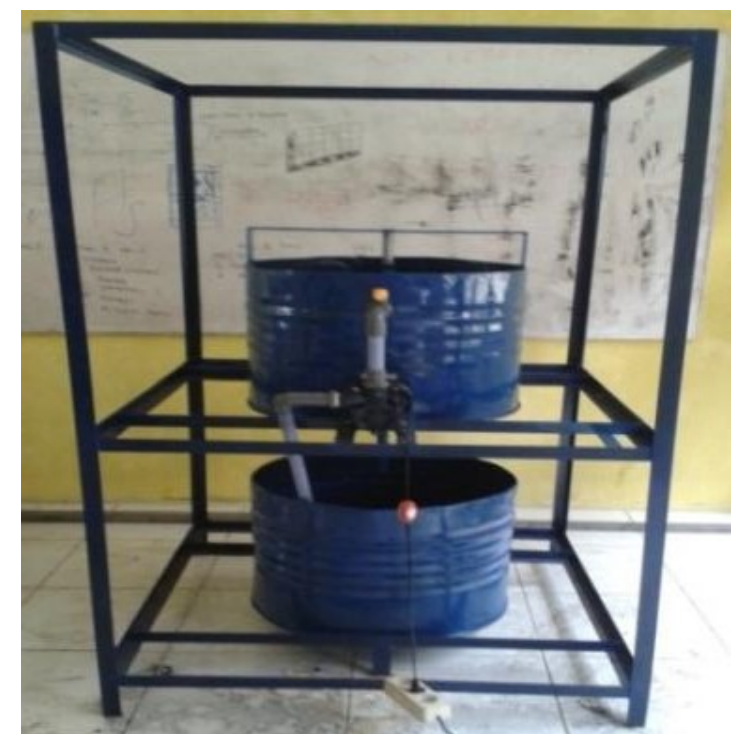

Gambar 3. Alat Uji Hardenability Jominy [6]

\subsubsection{Alat Uji Kekerasan}

Alat uji kekerasan bertujuan untuk menentukan kekerasan suatu material dalam 


\section{Jurnal Mekanova}

Vol 5. No. 2, Oktober 2019

ISSN : 2502-0498

bentuk daya tahan material terhadap bola baja yang ditekankan pada permukaan material uji tersebut (spesimen), seperti terlihat pada Gambar 4. 
Jurnal Mekanova

Vol 5. No. 2, Oktober 2019

ISSN : 2502-0498

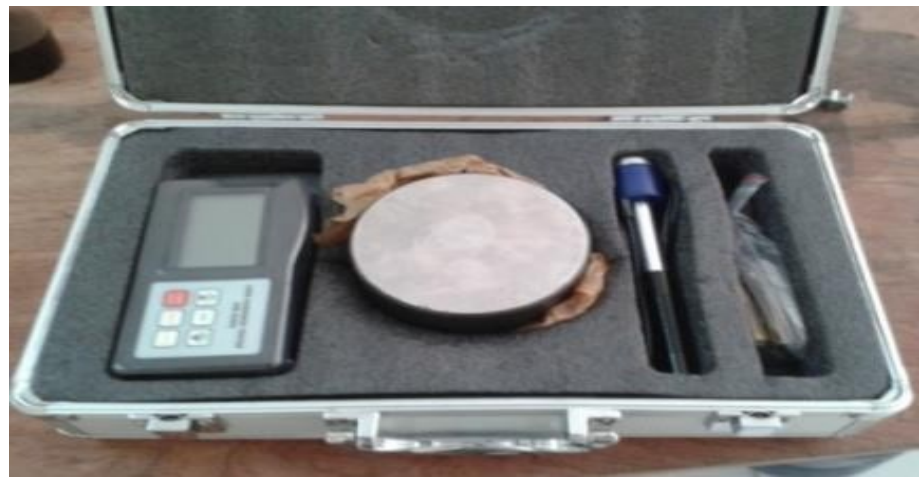

Gambar 4. Alat uji kekerasan

Spesifikasi alat uji Kekerasan :

\begin{tabular}{|c|c|}
\hline Nama Merek & Graigar \\
\hline Nomor Model & HМ-6560 \\
\hline Display & $12.5 \mathrm{~mm}$ LCD with back light \\
\hline Accuracy & Display error $\pm 0.8 \%$ at $\mathrm{LD}=900$ \\
\hline Measuring range & $200-900 \mathrm{~L}$ \\
\hline
\end{tabular}

\subsubsection{Dapur Pemanas}

Dapur pemanas bertujuan untuk memenaskan material uji sampai temperature austenisasinya. Lama pemanasan tergantung ketebalan bahan yaitu semakin tebal bahan yang dipanaskan semakin lama waktu yang diperlukan. Seperti terlihat pada Gambar 5.

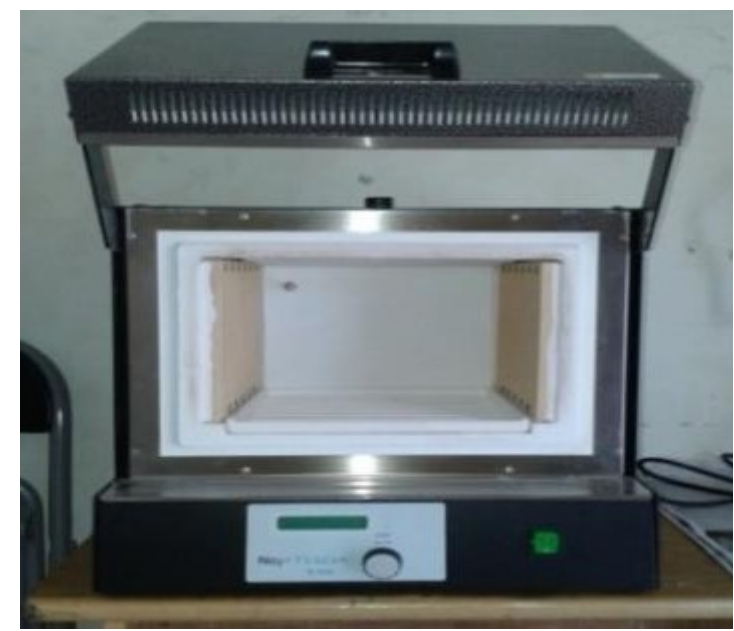

Gambar 5. Dapur pemanas

Spesifikasi Dapur Pemanas :

$\begin{array}{lll}\text { Nama Merek } & : & \text { Vulcan } \\ \text { Made in } & : & \text { Ceramco - USA. } \\ \text { Model } & : & \text { D-550 } \\ \text { Temp maksimal } & : & 1100{ }^{\circ} \mathrm{C} \\ \text { Dimensions ( external ) } & : & 630 \times 410 \times 400 \mathrm{~mm} \\ \text { Weigh } & : & 27 \mathrm{Kg} . \\ \text { Power } & : & 2400 \mathrm{Watt} \\ \text { Capacity } & : & 9.5 \mathrm{~L}\end{array}$


Vol 5. No. 2, Oktober 2019

ISSN : 2502-0498

\subsection{Tahap Pengujian}

Pengujian yang akan dilakukan menggunakan material baja tahan karat AISI 304 dengan langkah- langkah pengujian sebangai berikut :

1. Setelah dibubut spesimen di uji kekerasan untuk mendapatkan data awal

2. Normalizing spesimen dilakukan dengan memanaskan spesimen sampai suhu $850^{\circ} \mathrm{C}$ dan didingin dengan udara.

3. Setelah proses normalizing selesai spesimen di uji kekerasannya.

4. Tahap berikutnya adalah proses pengujian jominy dengan cara spesimen dipanaskan sampai suhu $850^{\circ} \mathrm{C}$ dan diletakkan pada alat jominy.

5. Dilanjutkan dengan pengujian kekerasan spesimen yang telah di jominy.

6. Data uji kekerasan awal, normalizing, dan jominy test, di plot menggunakan program excel untuk mendapatkan grafik tingkat kekerasan baja tahan karat AISI 304.

\subsection{Pengujian Jominy}

\section{III.HASIL DAN PEMBAHASAN}

\subsubsection{Pengukuran Kekerasan Spesimen Awal}

Sebelum melakukan pengujian, spesimen terlebih dahulu dibersihkan untuk membuat grid di dua bagian sisi spesimen (sisi A dan sisi B) agar memudahkan data pengujian. Jarak antara satu titik pengujian terhadap titik yang lain adalah $10 \mathrm{~mm}$. dan data pengujian di plot dalam Tabel 3 .

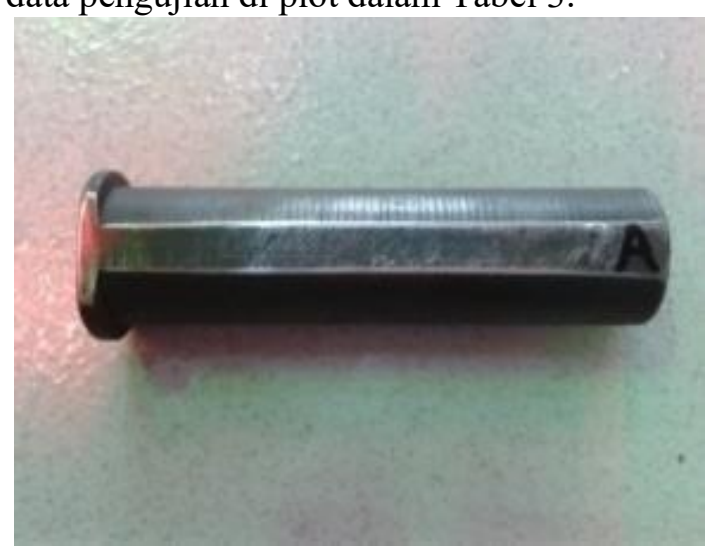

(A)

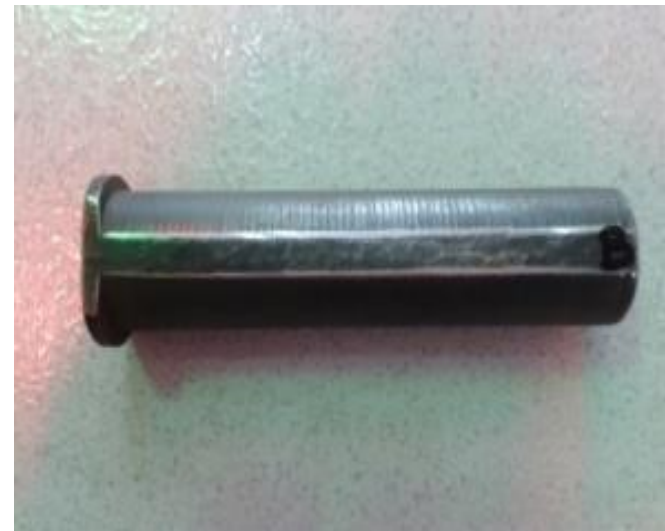

(B)

Gambar 6. Spesimen sisi A dan sisi B

Tabel 3. Pengukuran spesimen awal

\begin{tabular}{|c|c|c|c|}
\hline NO & Jarak (mm) & $\begin{array}{c}\text { Sisi Kekerasan A } \\
(\mathrm{HB})\end{array}$ & $\begin{array}{c}\text { Sisi Kekerasan B } \\
(\mathrm{HB})\end{array}$ \\
\hline 1 & 10 & 187 & 170 \\
\hline 2 & 20 & 211 & 197 \\
\hline 3 & 30 & 208 & 200 \\
\hline 4 & 40 & 213 & 211 \\
\hline 5 & 50 & 204 & 200 \\
\hline 6 & 60 & 215 & 204 \\
\hline 7 & 70 & 207 & 205 \\
\hline 8 & 80 & 205 & 210 \\
\hline
\end{tabular}


Jurnal Mekanova

Vol 5. No. 2, Oktober 2019

ISSN : 2502-0498

\begin{tabular}{|l|l|l|l|}
\hline 9 & 90 & 206 & 198 \\
\hline
\end{tabular}




\subsubsection{Proses Normalizing Spesimen}

Proses normalizing dilakukan pada temperature $850^{\circ} \mathrm{C}$ dipenahan temperature selama 15 menit dan didinginkan di udara selama $4 \mathrm{~s} / \mathrm{d} 5$ jam. Tujuan melakukan proses normalizing adalah untuk menormalkan kembali kondisi logam setelah mengalami perubahan struktur akibat fatik, dapat memperbaiki sifat-sifat mekanik dan menghilangkan struktur yang berbutir kasar yang diperoleh dari proses pengerjaan yang sebelumnya di alami oleh baja. Baja yang digunakan untuk pengujian ini bukan baja yang baru atau belum digunakan tetapi baja bekas dari tempat penampungan baja bekas. Maka untuk itu perlu dilakukan proses normalizing agar kondisi dari baja tersebut kembali normal. Data pengujian normalizing ditunjukan pada Tabel 4.

Tabel 4. Pengukuran spesimen proses normalizing

\begin{tabular}{|c|c|c|c|c|c|}
\hline NO & $\begin{array}{c}\text { Jarak } \\
(\mathrm{mm})\end{array}$ & $\begin{array}{c}\text { Sisi Kekerasan } \\
\text { A (HB) }\end{array}$ & $\begin{array}{c}\text { Sisi Kekerasan } \\
\text { B (HB) }\end{array}$ & $\begin{array}{c}\text { Peningkatan } \\
\text { Kekerasan Sisi } \\
\text { A (HB) }\end{array}$ & $\begin{array}{c}\text { Peningkatan } \\
\text { Kekerasan } \\
\text { Sisi B (HB) }\end{array}$ \\
\hline 1 & 10 & 182 & 188 & -5 & +18 \\
\hline 2 & 20 & 208 & 200 & -3 & +3 \\
\hline 3 & 30 & 210 & 208 & +2 & +8 \\
\hline 4 & 40 & 210 & 204 & -3 & -7 \\
\hline 5 & 50 & 208 & 203 & +4 & +3 \\
\hline 6 & 60 & 211 & 202 & -4 & -2 \\
\hline 7 & 70 & 206 & 211 & -1 & +6 \\
\hline 8 & 80 & 201 & 214 & -4 & +4 \\
\hline 9 & 90 & 187 & 196 & -19 & -2 \\
\hline
\end{tabular}

Terjadi penurunan kekerasan setelah normalizing pada sisi A dengan jarak quenching $10 \mathrm{~mm}=4 \mathrm{HB}, 20 \mathrm{~mm}=3 \mathrm{HB}, 40 \mathrm{~mm}=3 \mathrm{HB}, 60 \mathrm{~mm}=4 \mathrm{HB}, 70 \mathrm{~mm}=1$ $\mathrm{HB}, 80 \mathrm{~mm}=4 \mathrm{HB}, 90 \mathrm{~mm}=19 \mathrm{HB}$. Dan terjadi peningkatan kekerasan pada jarak 30 $\mathrm{mm}=2 \mathrm{HB}, 50 \mathrm{~mm}=4 \mathrm{HB}$.

Sedangkan pada sisi $\mathrm{B}$ terjadi penurunan kekerasan dengan jarak quenching 40 $\mathrm{mm}=7 \mathrm{HB}, 60 \mathrm{~mm}=2 \mathrm{HB}, 90 \mathrm{~mm}=2 \mathrm{HB}$. Dan terjadi peningkatan kekerasan dengan jarak quenching $10 \mathrm{~mm}=18 \mathrm{HB}, 20 \mathrm{~mm}=3 \mathrm{HB}, 30 \mathrm{~mm}=8 \mathrm{HB}, 50 \mathrm{~mm}=3 \mathrm{HB}, 70 \mathrm{~mm}$ $=6 \mathrm{HB}, 80 \mathrm{~mm}=4 \mathrm{HB}$.

\subsubsection{Proses Pengujian Jominy}

Sebelum proses pengujian jomini dilakukan, spesimen terlebih dahulu di lakukan pengujian normalizing atau pendinginan udara untuk memperbaiki sifat-sifat mekanik dari baja tahan karat AISI 304. Proses pengujian jominy dilakukan pada temperature $850^{\circ} \mathrm{C}$ dan waktu penahan selama 15 menit. Kemudian spesimen didinginkan pada alat uji jominy dengan debit aliran air 45 liter/menit, dan laju pendinginan 3-5 menit. Hasil pengujian jominy baja tahan karat AISI 304 ditunjukkan pada Tabel 5.

Tabel 5. Pengukuran spesimen pengujian jominy

\begin{tabular}{|c|c|c|c|c|c|}
\hline NO & Jarak & Sisi Kekerasan & Sisi Kekerasan & Peningkatan \\
& $(\mathrm{mm})$ & A (HB) & B (HB) & $\begin{array}{c}\text { Peningkatan } \\
\text { Kekasan Sisi } \\
\text { A (HB) }\end{array}$ & $\begin{array}{c}\text { Kekerasan Sisi } \\
\text { B (HB) }\end{array}$ \\
\hline
\end{tabular}


Jurnal Mekanova

Vol 5. No. 2, Oktober 2019

ISSN : 2502-0498

\begin{tabular}{|l|l|l|l|l|l|}
\hline 1 & 10 & 227 & 223 & +45 & +35 \\
\hline
\end{tabular}


Vol 5. No. 2, Oktober 2019

ISSN : 2502-0498

\begin{tabular}{|c|c|c|c|c|c|}
\hline 2 & 20 & 220 & 216 & +12 & +16 \\
\hline 3 & 30 & 219 & 214 & +9 & +6 \\
\hline 4 & 40 & 218 & 213 & +8 & +9 \\
\hline 5 & 50 & 214 & 210 & +6 & +7 \\
\hline 6 & 60 & 213 & 205 & +2 & +3 \\
\hline 7 & 70 & 211 & 204 & +5 & -7 \\
\hline 8 & 80 & 203 & 185 & +2 & -29 \\
\hline 9 & 90 & 181 & 178 & -6 & -18 \\
\hline
\end{tabular}

Terjadi peningkatan kekerasan setelah di jominy pada sisi A dengan jarak quenching $10 \mathrm{~mm}=45 \mathrm{HB}, 20 \mathrm{~mm}=12 \mathrm{HB}, 30 \mathrm{~mm}=9 \mathrm{HB}, 40 \mathrm{~mm}=8 \mathrm{HB}, 50 \mathrm{~mm}=6$ $\mathrm{HB}, 60 \mathrm{~mm}=2 \mathrm{HB}, 70 \mathrm{~mm}=5 \mathrm{HB}, 80 \mathrm{~mm}=2 \mathrm{HB}$. Dan terjadi peurunan kekerasan pada jarak $90 \mathrm{~mm}=6 \mathrm{HB}$.

Sedangkan pada sisi $\mathrm{B}$ terjadi peningkatan kekerasan dengan jarak quenching 10 $\mathrm{mm}=35 \mathrm{HB}, 20 \mathrm{~mm}=16 \mathrm{HB}, 30 \mathrm{~mm}=6 \mathrm{HB}, 40 \mathrm{~mm}=9 \mathrm{HB}, 50 \mathrm{~mm}=7 \mathrm{HB}, 60 \mathrm{~mm}$ $=3 \mathrm{HB}$. Dan terjadi penurunan kekerasan dengan jarak quenching $70 \mathrm{~mm}=7 \mathrm{HB}, 80 \mathrm{~mm}$ $=29 \mathrm{HB}, 90 \mathrm{~mm}=18 \mathrm{HB}$.

\subsection{Pengaruh Tingkat Kekerasan Spesimen Terhadap Uji Jominy}

\subsubsection{Tingkat Kekerasan Awal Spesimen AISI 304}

Untuk hasil kekerasan awal spesimen baja tahan karat AISI 304 untuk kedua sisi di plot dalam Gambar 7.

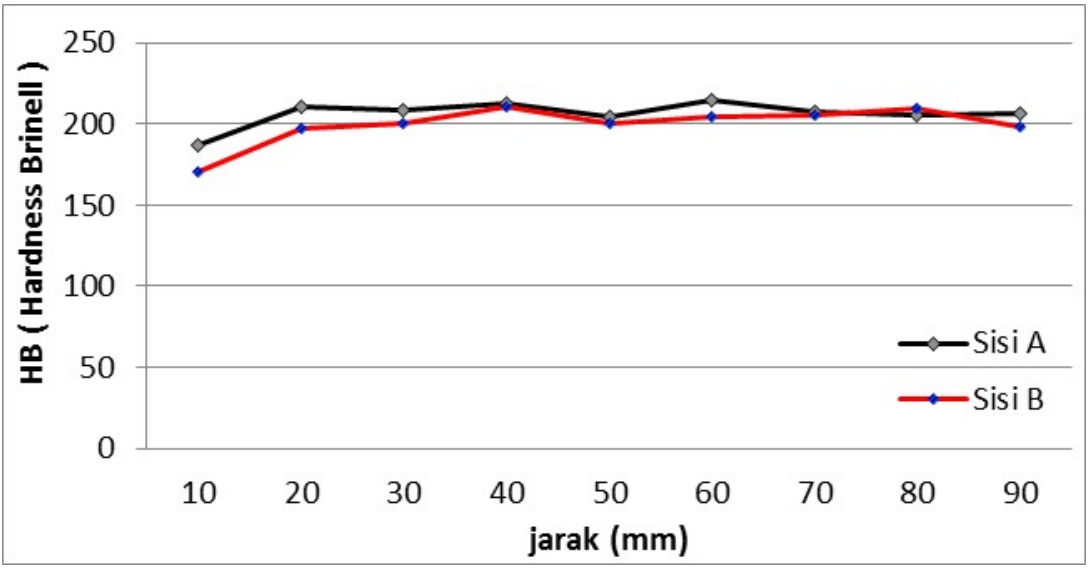

Gambar 7. Grafik spesimen uji sebelum di panaskan

Kekerasan spesimen awal sisi A pada ujung quenching adalah $187 \mathrm{HB}$. Dan pada sisi B adalah $170 \mathrm{HB}$.

3.2.2. Tingkat Kekerasan Normalizing Spesimen AISI 304

Untuk hasil kekerasan normalizing spesimen baja tahan karat AISI 304 untuk kedua sisi di plot dalam Gambar 8. 
Vol 5. No. 2, Oktober 2019

ISSN : 2502-0498

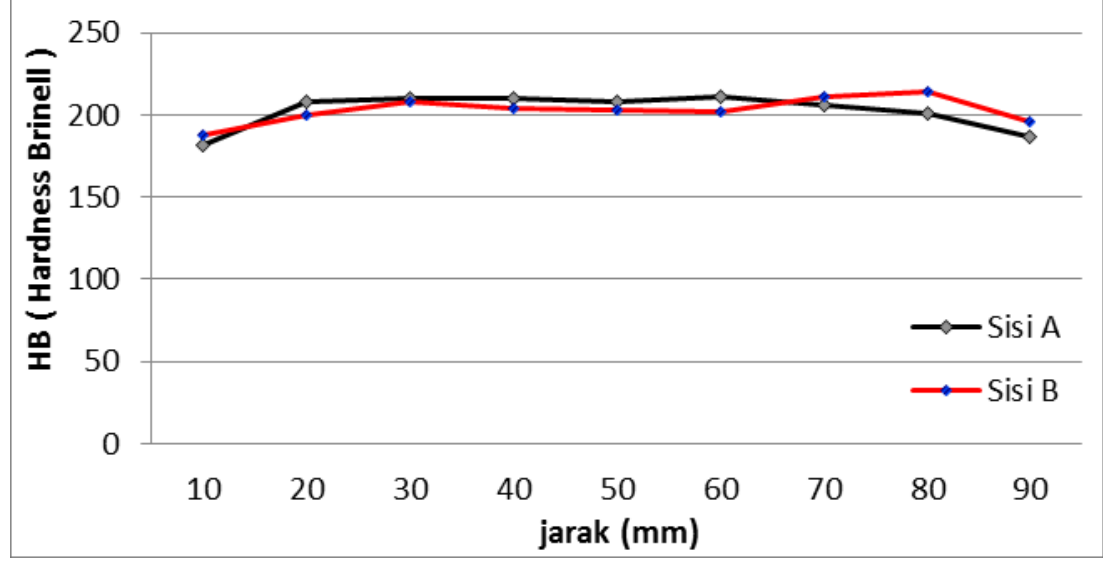

Gambar 8. Grafik spesimen pengujian normalizing

Setelah dilakukan normaling kekerasan sisi A pada ujung quenching berubah menjadi 182 HB. Dan pada sisi B adalah 188 HB.

3.2.3. Tingkat Kekerasan Uji Jominy Spesimen AISI 304

Untuk hasil kekerasan uji jominy spesimen baja tahan karat AISI 304 untuk kedua sisi di plot pada Gambar 9

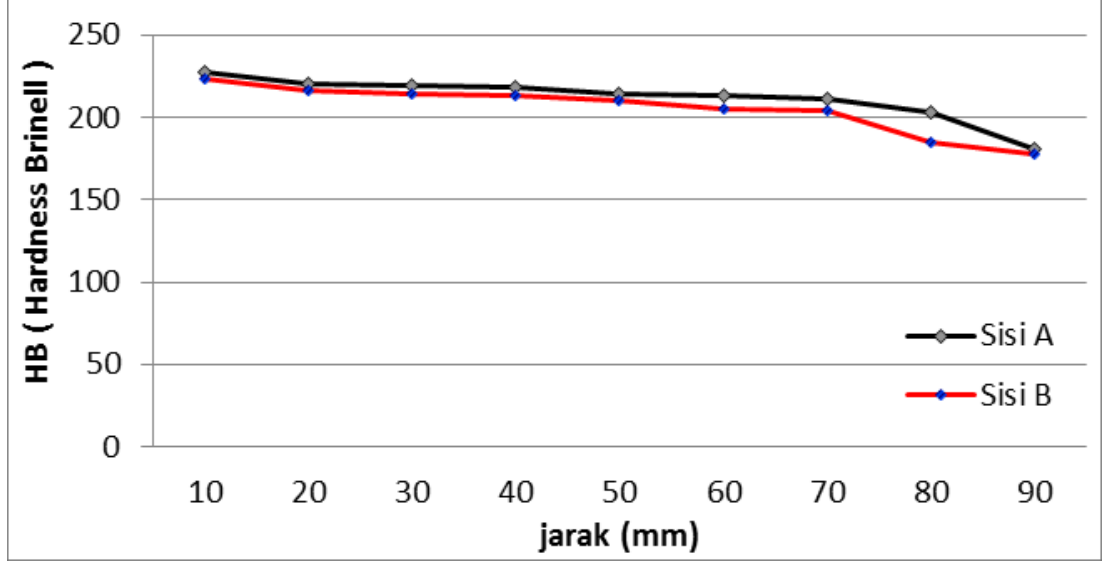

Gambar 9. Grafik spesimen pengujian jominy

Hasil kekerasan yang di dapatkan setelah melakukan uji jominy pada sisi A pada ujung quenching adalah $227 \mathrm{HB}$. Dan pada sisi B adalah $223 \mathrm{HB}$.

Baja tahan karat AISI 304 mempunyai sifat mekanik dan ketahanan korosi yang lebih tinggi. Setelah dilakukan Hardenability maka terjadi peningkatan kekerasan pada ujung quenching sisi A sebelum di Jominy $182 \mathrm{HB}$ dan setelah di Jomini menjadi 227 $\mathrm{HB}$, sedangkan pada ujung quenching sisi B sebelum di Jominy $188 \mathrm{HB}$ dan setelah di Jominy menjadi 223 HB. Maka pada ujung quenching sisi A terjadi peningkatan kekerasan sebesar $45 \mathrm{HB}$, dan pada Sisi B terjadi peningkatan kekerasan sebesar $35 \mathrm{HB}$.

\subsection{Hasil Kekerasan Baja Tahan Karat AISI 304}

\subsubsection{Hasil Kekerasan Sisi A Pada Baja Tahan Karat AISI 304}

Untuk hasil kekerasan pada sisi A spesimen baja tahan karat AISI 304 di plot pada Gambar 10. 
Vol 5. No. 2, Oktober 2019

ISSN : 2502-0498

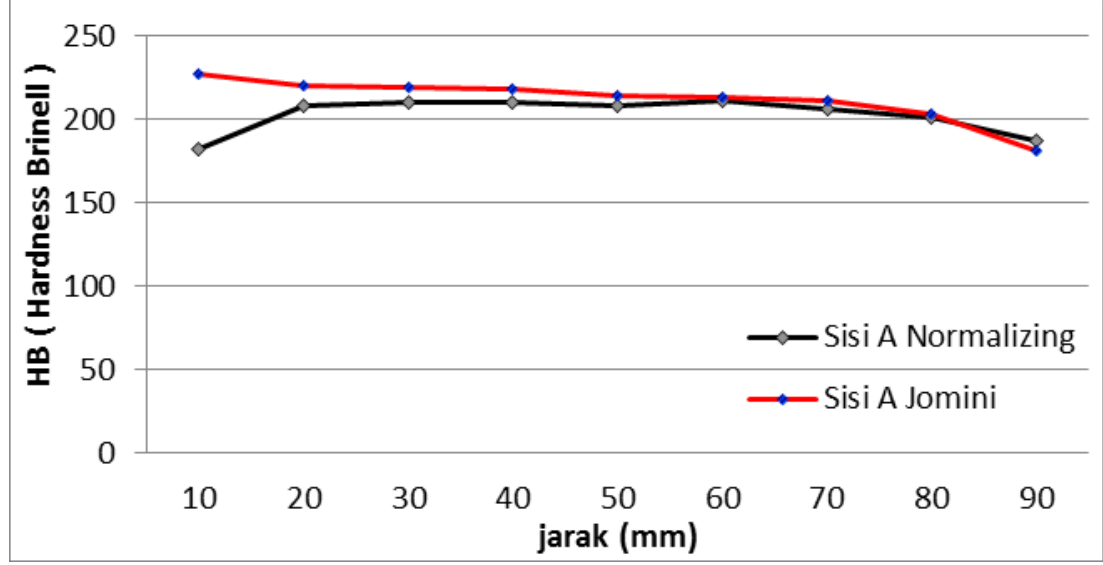

Gambar 10. Grafik hasil uji kekerasan sisi A baja tahan karat AISI 304

Setelah dilakukan normaling kekerasan sisi A pada ujung quenching berubah menjadi 182 HB. Dan setelah dilakukan uji jomini hasil kekerasan yang di dapatkan pada sisi A pada ujung quenching adalah $227 \mathrm{HB}$. Terjadi peningkatan kekerasan pada ujung quench setelah di uji jomini yaitu sebesar $45 \mathrm{HB}$.

\subsubsection{Hasil Kekerasan Sisi B Pada Baja Tahan Karat AISI 304}

Untuk hasil kekerasan pada sisi B spesimen baja tahan karat AISI 304 di plot dalam Gambar 11.

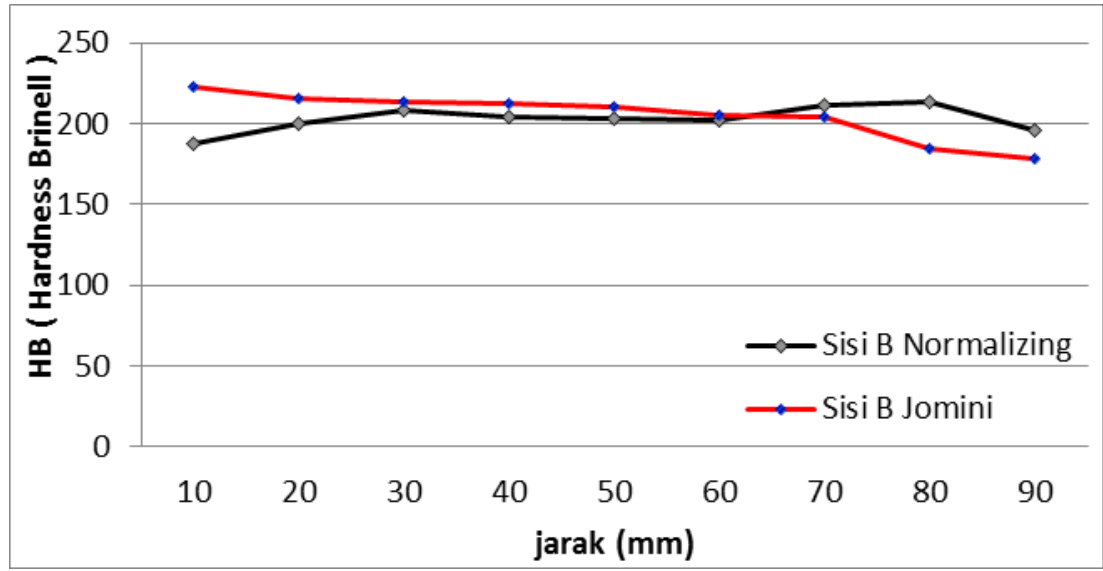

Gambar 11. Grafik hasil uji kekerasan sisi B baja tahan karat AISI 304

Setelah dilakukan normaling kekerasan sisi B pada ujung quenching berubah menjadi 188 HB. Dan setelah dilakukan uji jomini hasil kekerasan yang di dapatkan pada sisi B pada ujung quenching adalah $223 \mathrm{HB}$. Terjadi peningkatan kekerasan pada ujung quench setelah di uji jomini yaitu sebesar $35 \mathrm{HB}$.

\subsection{Kesimpulan}

\section{PENUTUP}

1. Nilai awal kekerasan pada ujung quenching spesimen baja tahan karat AISI 304 pada sisi A adalah $187 \mathrm{HB}$, dan pada sisi B adalah $170 \mathrm{HB}$

2. Setelah melakukan proses pendinginan udara (Normalizing) nilai kekerasan pada ujung quenching sisi A adalah $182 \mathrm{HB}$, dan pada sisi B adalah $188 \mathrm{HB}$. Maka terjadi penurunan kekerasan pada sisi A sebesar 5 HB dan pada sisi B terjadi 
Jurnal Mekanova

Vol 5. No. 2, Oktober 2019

ISSN : 2502-0498

peningkatan kekerasan sebesar $18 \mathrm{HB}$ 
3. Pada proses pengujian Jominy nilai kekerasan pada ujung quenching sisi A terjadi peningkatan kekerasan sebesar $45 \mathrm{HB}$ dan pada sisi B terjadi Peningkatan kekerasan sebesar 35 HB. Maka nilai kekerasan setalah di Jominy pada sisi A yaitu $227 \mathrm{HB}$, dan pada sisi B yaitu $223 \mathrm{HB}$

4. Untuk baja tahan karat AISI 304 nilai kekerasan max 195 HB.

\subsection{Saran}

Setelah melakukan penelitian uji Hardenability Jominy ada kekurangan yang belum bisa dilakukan karna terbatasnya alat pengujian sehingga untuk melihat struktur mikro dari spesimen yang telah di uji kekerasannya tidak dapat di lihat bagaimana perubahan yang terjadi sebelum dilakukan pengujian dan sesudah pengujian Hardenability. Untuk penelitian selanjutnya diharapkan bisa melihat struktur mikro dari material yang akan digunakan dalam proses penelitian, dan mahasiswa bisa lebih mengerti manfaat kekerasan dari baja tersebut.

\section{DAFTAR PUSTAKA}

[1]. Lawrence H. Van Vlack, Sriati Djaprie.(1991). Ilmu dan Teknologi Bahan.Jakarta:Erlangga.

[2]. William D. Callister, Jr, 1993.Material Science and Engineering 3d.New York: John Wiley\& Sons.

[3]. ASTM A 255-02, ASTM A370-02, Standart Test Method for and-Quench Test for Hardenability of Steel.

[4]. Metal Handbook, Vol 1, America Society for Metal, Ohio, 1961.

[5]. Shigley dan Joseph Edward, 1994, Perencanaan Teknik Mesin, Erlangga. Jakarta.

[6]. H. Susanto dkk, Rancang Bangun Alat Uji Jominy, Jurnal Mekanova Vol. 2 No. 3 Oktober 2016, Halaman 106-116, Jurusan Teknik Mesin Universitas Teuku Umar. 